\title{
EFFECTS OF PNEUMOPERITONEUM AND TRENDELENBURG POSITION ON INTRAOCULAR PRESSURE (IOP) IN ISOFLUORANE ANESTHETISED CATS
}

\author{
EFEITOS DO PNEUMOPERITÔNIO E DA POSIÇÃO DE TRENDELENBURG \\ SOBRE A PRESSÃO INTRAOCULAR (PIO) EM GATOS ANESTESIADOS COM \\ ISOFLURANO
}

\section{Arilton Teodoro de SOUZA ${ }^{\mathbf{1}}$; Débora de Oliveira GARCIA ${ }^{\mathbf{1}}$ Lilian Toshiko NISHIMURA $^{\mathbf{1}}$; Marcos Lúcio MAGALHÃES ${ }^{1}$; Ewaldo MATTOS-JUNIOR ${ }^{1}$; Daniel PAULINO-JUNIOR ${ }^{1}$; Adriana Torrecilhas JORGE ${ }^{1}$; Cristiane dos Santos HONSHO ${ }^{*}$ \\ 1. Postgraduate Program in Veterinary Science at the University of Franca- UNIFRAN, Franca, SP, Brazil. cristiane.honsho@unifran.edu.br}

\begin{abstract}
The aim of this study was to determine whether a pneumoperitoneum of $10 \mathrm{mmHg}$ combined or not with the Trendelenburg position could lead to significant changes in intraocular pressure (IOP), ocular pressure perfusion (OPP), and cardiorespiratory variables; as well as determine whether a correlation exists between IOP and mean arterial blood pressure (MAP), and/or partial pressure of carbon dioxide in arterial blood $\left(\mathrm{PaCO}_{2}\right)$ in cats. Animals were allocated in two groups ( $\mathrm{n}=7 /$ group): $\mathrm{GC}$ (without inclination) and GTREN (Trendelenburg position). The variables were recorded before (baseline) and during 30 minutes (T5-T30) after insufflation. In GTREN, a reduction in heart rate was observed at T5 and in respiratory rate at T5 and T15. There was an increase in IOP at T5-T30 in comparison to baseline. There was a reduction in potential of hydrogen in arterial blood in both groups at all times in comparison to baseline. Partial pressure of carbon dioxide in arterial blood was increased at T15-T30 in GC and at T5-T30 in GTREN. In conclusion, the pneumoperitoneum of $10 \mathrm{mmHg} \mathrm{CO}_{2}$ did not significantly affect IOP or OPP in cats anaesthetised with isofluorane and kept under spontaneous ventilation. However, induced pneumoperitoneum combined with Trendelenburg position resulted in an increase in IOP in cats subjected to the same anaesthetic conditions, but did not affect OPP.
\end{abstract}

KEYWORDS: Intra-abdominal pressure. Body position. Ocular alterations. Pressure. Videolaparoscopy. Videosurgery.

\section{INTRODUCTION}

Video-assisted procedures provide several benefits to conventional surgeries, one of which is being minimally invasive (CASE et al., 2015), but require the establishment of pneumoperitoneum and/or Trendelenburg position, can cause cardiac output reduction and increase of $\mathrm{PaCO}_{2}$ (LEME et al., 2002; PEDROSO et al., 2007).

Several studies have analysed the influence of Trendelenburg position on the increase in IOP in several species (AWAD et al., 2009; HONSHO et al., 2013), including the loss of vision in humans subjected to this position for long periods (AWAD et al., 2009; KUMAR; VYAKARNAM, 2013). However, little has been reported of its effects on the IOP in cats.

The combination of pneumoperitoneum and Trendelenburg position can lead to physiological alterations like increase of MAP, $\mathrm{PaCO}_{2}$, and IOP that can result in ischemic lesions of the optical nerve associated with blindness (KUMAR; VYAKARNAM, 2013; BASSO et al., 2014) especially in the presence of alterations that could influence the ocular pressure perfusion (OPP) such as pre-existing cardiorespiratory diseases, hypervolemia or haemodilution (MOLLOY, 2011).

This study aimed to evaluate if a pneumoperitoneum of $10 \mathrm{mmHg}$ combined or not with the Trendelenburg position could lead to significant changes in IOP, OPP, and cardiorespiratory variables; as well as determine whether a correlation exists between IOP and MAP, and/or $\mathrm{PaCO}_{2}$ in cats.

\section{MATERIAL AND METHODS}

Fourteen ( 3 males and 11 females) healthy young adult cats of mixed breed and weighing $2.8 \pm$ $0.9 \mathrm{~kg}$ were used in this study. The animals were obtained from the São Francisco Veterinary Hospital, Mogi Mirim - SP, Brazil and included in 
the study following a verbal and written consent by the owners. The animals were subjected to clinical examination and laboratory analysis. The study took place at the University of Franca, Franca/SP, Brazil. An eight-hour fasting was implemented prior to the study.

The animals were allocated in random order into two groups $(\mathrm{n}=7)$, Control $\left(\mathrm{GC}-180^{\circ}\right.$ dorsal decubitus - no inclination) and Trendelenburg (GTREN - dorsal decubitus at $20^{\circ}$ Trendelenburg position (head-down tilt). All groups were subjected to an induced pneumoperitoneum of $10 \mathrm{mmHg}$ with carbon dioxide $\left(\mathrm{CO}_{2}\right)$. The inclination angle was obtained using a protractor.

Induction to anesthesia was performed with isoflurane in concentration previously established in pilot study (inspired fraction $=3,6 \%$ ) using an induction box. After appropriate mandibular relaxation, the trachea was intubated with a Magill endotracheal tube and connected to Mapleson's D breathing system. Anesthesia was maintained with isofluorane (diluted in $100 \%$ oxygen at 100 $\mathrm{mL} / \mathrm{kg} / \mathrm{min}$ ) in concentration determined by stage of anaesthesia based on rotation of the ocular globe, HR and MAP. All animals' receive intravenous Ringer Lactate solution ( $5 \mathrm{~mL} / \mathrm{kg} /$ hour $)$ during the observation period.

A Veress needle was inserted in the umbilical region and the linea alba and connected to the insufflator, generating a $\mathrm{CO}_{2}$ pneumoperitoneum of $10 \mathrm{mmHg}$ at $1 \mathrm{~L} / \mathrm{min}$.

Intraocular pressure (right and left) was determined by applanation tonometry using TonoPen Avia $^{\mathrm{TM}}$ (Reichert Inc., NY, USA) after instillation of $0.5 \%$ proparacaine anaesthetic eye drops (Anestalcon - Alcon Lab. Brasil Ltda, São Paulo, Brazil). Analysis took place between 1 and 6 $\mathrm{pm}$ and the equipment was calibrated according to the manufacturer's recommendations prior to the start of the study. At least three measurements were recorded, with a 5\% error margin. Readings were taken by the same experienced professional, with animals in dorsal decubitus and the head positioned at the level of the thoracic vertebrae. OPP was considered as the difference between IOP and MAP.

Heart rate (HR, bpm - beats per minute) was determined using a digital electrocardiograph (TEB, ECGPC, São Paulo, Brazil) in which the R-R interval during 1 minute. Mean arterial blood pressure (MAP - mmHg - millimetres of mercury) was evaluated using the catheter percutaneous inserted in left or right medial tarsal artery and connected to a system filled with $0.1 \%$ heparin solution $(50 \mathrm{IU} / \mathrm{mL})$. Pressure was measured intermittently using a monitor (Dash 4000, GE HealthCare, UK), which was calibrated against a mercury column before use. Prior to measurement, the system was zeroed using the air-saline junction at the point of the shoulder in dorsal recumbent animals in the xiphoid process as reference points. Rectal temperature $\left(\mathrm{RT},{ }^{\circ} \mathrm{C}\right)$ was determined by a clinical thermometer (Termômetro Clínico BD, BD, MG, Brazil) and $f$ (bpm - breaths per minute) determined by the number of chest movements observed in 1 minute.

Arterial blood gas analysis [pHa, $\mathrm{PaCO}_{2}$, $\mathrm{PaO}_{2}(\mathrm{mmHg}), \mathrm{HCO}_{3}^{-}, \mathrm{BE}(\mathrm{mmol} / \mathrm{L})$ and $\mathrm{SaO}_{2}(\%)$ were determined by heparinised samples $(0.5 \mathrm{~mL})$ collected from the catheter in the tarsal artery used to measure arterial pressure and immediately analysed using a blood $\mathrm{pH}$ and gas analyser (Cobas b 121 Roche $^{\circledR}$, Basileia, Switzerland).

The variables were recorded before any medication (T0), immediately before insufflation (TBINS), and at 5 (T5), 15 (T15), and 30 minutes after insufflation (T30). Following data collection, the animals underwent ovariohysterectomy or orchiectomy.

Data are expressed as mean \pm standard deviation. Comparisons within the groups at the different times were performed using ANOVA and Bonferroni post-hoc test. Comparison between the groups at the different times was performed by paired t-test. Analysis was carried out using the statistical program GraphPad PRISM v. 5 (GraphPad Software, Inc, La Jolla, CA, USA). Significance was considered at $5 \%(\mathrm{P} \leq 0.05)$.

\section{RESULTS}

The time TBINS was considered baseline for statistical analysis and comparison of variables within the groups. As there were no significant differences in IOP between the right and left eyes, the data from both were grouped together. The mean inspired fraction of isoflurane was $1.6 \pm 0.2 \%$. Mean values of the HR, $f$, RT, MAP, CVP, blood gas analasys and OPP are presented in Table 1.

In GTREN, there was a significant $(\mathrm{P}=0.035)$ reduction in $\mathrm{HR}$ at $\mathrm{T} 5$. Mean $f$ in GTREN was significantly $(\mathrm{P}=0.007)$ lower at $\mathrm{T} 5$ and T15. In GTREN mean $f$ was significantly lower than in $\mathrm{GC}$ at $\mathrm{T} 5(\mathrm{P}=0.003)$ and $\mathrm{T} 15(\mathrm{P}=0.040)$. There was a significant reduction in $\mathrm{RT}$ in $\mathrm{GC}$ $(\mathrm{P}<0.0001)$ and GTREN $(\mathrm{P}<0.0001)$ at T5-T30. In GTREN, RT was significantly lower than GC at $\mathrm{T} 15(\mathrm{P}=0.036)$ and $\mathrm{T} 30(\mathrm{P}=0.007)$. In $\mathrm{GC}$, there was a significant $(\mathrm{P}=0.039)$ increase in MAP at $\mathrm{T} 15$. 
Table 1. Mean $\pm \mathrm{SD}$ of heart rate (HR), respiratory rate $(f)$, rectal temperature (RT), mean arterial pressure (MAP), central venous pressure (CVP), potential hydrogen in arterial blood $(\mathrm{pHa})$, partial pressure of carbon dioxide in arterial blood $\left(\mathrm{PaCO}_{2}\right)$, partial pressure of oxygen in arterial blood $\left(\mathrm{PaO}_{2}\right)$, oxygen saturation of arterial blood $\left(\mathrm{SaO}_{2}\right)$, bicarbonate $\left(\mathrm{HCO}_{3}{ }^{-}\right)$and base excess (BE) in cats anaesthetised with isoflurane and kept under spontaneous ventilation, and subjected to induced pneumoperitoneum of $10 \mathrm{mmHg}$ alone (GC) or combined with $20^{\circ}$ Trendelenburg position (GTREN) at different times of evaluation.

\begin{tabular}{|c|c|c|c|c|c|c|c|}
\hline Variable & Group & T0 & TBINS & T5 & T15 & T30 & $P($ ANOVA $)$ \\
\hline \multirow{2}{*}{$\begin{array}{l}\mathrm{HR} \\
\text { (bpm) }\end{array}$} & GC & $177 \pm 5$ & $150 \pm 3$ & $153 \pm 2$ & $148 \pm 2$ & $140 \pm 1$ & 0.255 \\
\hline & GTREN & $184 \pm 8$ & $157 \pm 2$ & $139 \pm 3 *$ & $142 \pm 3$ & $147 \pm 3$ & 0.035 \\
\hline \multirow{2}{*}{$\begin{array}{l}f \\
(\mathrm{bpm})\end{array}$} & $\mathrm{GC}$ & $43 \pm 12$ & $29 \pm 9$ & $25 \pm 8$ & $27 \pm 10$ & $23 \pm 11$ & 0.299 \\
\hline & GTREN & $53 \pm 24$ & $23 \pm 8$ & $14 \pm 7^{*}$ & $17 \pm 5^{*}$ & $18 \pm 7$ & 0.007 \\
\hline \multirow{2}{*}{$\begin{array}{l}\mathrm{RT} \\
\left({ }^{\circ} \mathrm{C}\right)\end{array}$} & GC & $38.2 \pm 0.9$ & $37.6 \pm 0.7$ & $\begin{array}{l}36.9 \\
0.72 *\end{array}$ & $37 \pm 0.7^{*}$ & $36.5 \pm 0.6^{*}$ & 0.0001 \\
\hline & GTREN & $37.7 \pm 0.6$ & $37 \pm 0.7$ & $36.2 \pm 0.4^{*}$ & $36.1 \pm 0.3^{*}$ & $35.7 \pm 0.4^{*}$ & 0.0001 \\
\hline $\begin{array}{l}\text { MAP } \\
(\mathrm{mmHg})\end{array}$ & $\mathrm{GC}$ & - & $65 \pm 9$ & $78 \pm 15$ & $75 \pm 11 *$ & $72 \pm 6$ & 0.039 \\
\hline $\begin{array}{l}\text { CVP } \\
(\mathrm{cmH} 2 \mathrm{O})\end{array}$ & $\begin{array}{l}\text { GTREN } \\
\text { GC } \\
\text { GTREN }\end{array}$ & $\begin{array}{l}- \\
-\end{array}$ & $\begin{array}{l}75 \pm 21 \\
7 \pm 4 \\
2 \pm 2\end{array}$ & $\begin{array}{l}70 \pm 22 \\
4 \pm 3 \\
2 \pm 4\end{array}$ & $\begin{array}{l}73 \pm 30 \\
5 \pm 3 \\
1 \pm 4\end{array}$ & $\begin{array}{l}75 \pm 22 \\
5 \pm 5 \\
0.28 \pm 3.81\end{array}$ & $\begin{array}{l}0.540 \\
0.353 \\
0.200\end{array}$ \\
\hline \multirow{2}{*}{$\mathrm{pHa}$} & GC & - & $\begin{array}{l}7.29 \\
0.06\end{array}$ & $\begin{array}{l}7.23 \\
0.09^{*}\end{array}$ & $7.20 \pm 0.1^{*}$ & $7.18 \pm 0.09 *$ & 0.0002 \\
\hline & GTREN & - & $\begin{array}{l}7.31 \quad \pm \\
0.08\end{array}$ & $\begin{array}{l}7.19 \\
0.08^{*}\end{array}$ & $7.18 \pm 0.08^{*}$ & $7.18 \pm 0.09 *$ & 0.0003 \\
\hline $\mathrm{PaCO} 2$ & $\mathrm{GC}$ & - & $39 \pm 7$ & $48 \pm 16$ & $53 \pm 16^{*}$ & $54 \pm 15^{*}$ & 0.002 \\
\hline$(\mathrm{mmHg})$ & GTREN & - & $37 \pm 7$ & $53 \pm 10 *$ & $56 \pm 13^{*}$ & $55 \pm 13^{*}$ & 0.0002 \\
\hline $\mathrm{PaO} 2$ & $\mathrm{GC}$ & - & $359 \pm 51$ & $397 \pm 80$ & $364 \pm 71$ & $353 \pm 83$ & 0.204 \\
\hline$(\mathrm{mmHg})$ & GTREN & - & $304 \pm 145$ & $404 \pm 58$ & $381 \pm 37$ & $352 \pm 9$ & 0.128 \\
\hline $\mathrm{SaO} 2$ & $\mathrm{GC}$ & - & $99 \pm 0$ & $99 \pm 0$ & $99 \pm 0$ & $99 \pm 0$ & 0.063 \\
\hline$(\%)$ & GTREN & - & $99 \pm 1$ & $99 \pm 0$ & $98 \pm 0$ & $99 \pm 0$ & 0.329 \\
\hline $\mathrm{HCO} 3-$ & $\mathrm{GC}$ & - & $18 \pm 1$ & $19 \pm 2$ & $19 \pm 2$ & $19 \pm 1.8$ & 0.343 \\
\hline$(\mathrm{mmol} / \mathrm{L})$ & GTREN & - & $18 \pm 0.7$ & $20 \pm 1^{*}$ & $20 \pm 1.6^{*}$ & $20 \pm 1.6^{*}$ & 0.002 \\
\hline $\mathrm{BE}$ & $\mathrm{GC}$ & - & $-7.7 \pm 1.6$ & $-7.9 \pm 1.8$ & $-9.9 \pm 4.8$ & $-8.8 \pm 1.8$ & 0.202 \\
\hline$(\mathrm{mmol} / \mathrm{L})$ & GTREN & - & $-7.0 \pm 1.7$ & $-8 \pm 2.2$ & $-8.3 \pm 2.2 *$ & $-8.3 \pm 2.1^{*}$ & 0.0001 \\
\hline OPP & $\mathrm{GC}$ & - & $45 \pm 9$ & $56 \pm 13$ & $53 \pm 10$ & $52 \pm 6$ & 0.210 \\
\hline$(\mathrm{mmHg})$ & GTREN & - & $57 \pm 21$ & $58 \pm 21$ & $38.9 \pm 21$ & $45 \pm 22$ & 0.292 \\
\hline
\end{tabular}

SD: Standard deviation.; bpm: beats per minute - HR or breaths per minute - $f$;- Not available; * Significant difference in comparison to baseline (TBINS). Significance was considered at $\mathrm{P} \leq 0.05$.

There was a significant reduction in $\mathrm{pHa}$ in $\mathrm{GC}(\mathrm{P}=0.0002)$ and GTREN $(\mathrm{P}=0.0003)$ at T5-T30. In $\mathrm{GC}, \mathrm{PaCO}_{2}$ was significantly $(\mathrm{P}=0.002)$ increased at T15 and T30 while in GTREN it was significantly $(\mathrm{P}=0.0002)$ higher than TBINS at all times. In GTREN, $\mathrm{HCO}_{3}^{-}$was significantly $(\mathrm{P}=0.002)$ higher at T5-T30. There were a significant difference in $\mathrm{BE}$ in GTREN at $\mathrm{T} 15$ and T30 $(\mathrm{P}=0.0001)$

In GTREN, IOP was significantly $(\mathrm{P}<0.0001)$ higher at $\mathrm{T} 5, \mathrm{~T} 15$, and $\mathrm{T} 30$ comparatively to baseline. In GTREN this parameter was significantly $(\mathrm{P}=0.005)$ higher at $\mathrm{T} 30$ than in GC (Figure 1).

There was a weak positive correlation between IOP and MAP $(r=0.459)$ but no significant correlation was observed between $\mathrm{PaCO}_{2}$ and IOP ( $\mathrm{r}$ $=-0.05)$. No significant variation was observed in others parameters analysed. 


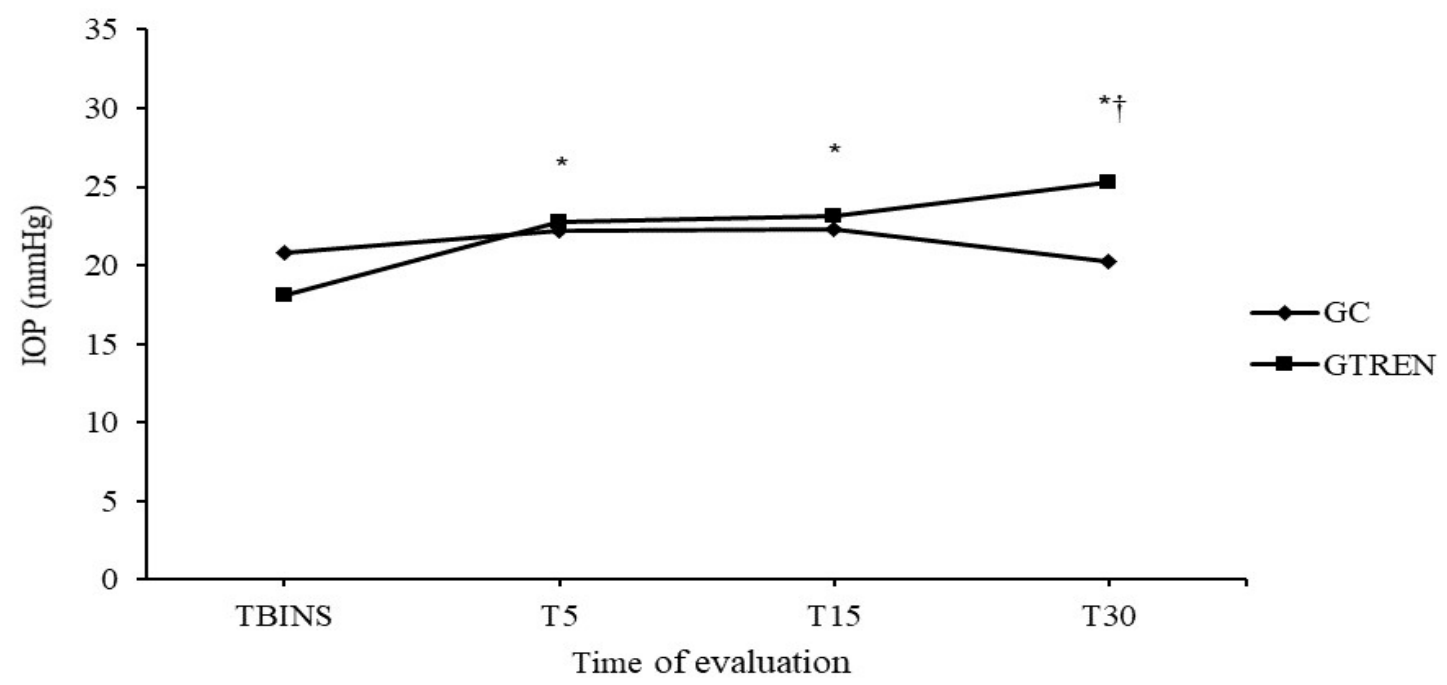

Figure 1. Mean values of the intraocular pressure (IOP) in cats submitted to pneumoperitoneum alone (GC) and combined with Trendelenburg position (GTREN) in different time of evaluation (TBINS: before insufflation, five, ten and third minutes after insufflation $\mathrm{T} 5, \mathrm{~T} 10$ and $\mathrm{T} 15$, respectively). *Significantly different from TBINS within the same treatment $(p<0.0001)$. †Significantly different from other group at the same time point $(p=0.010)$.

\section{DISCUSSION}

The present study hypothesized that pneumoperitoneum, alone or combined with o Trendelenburg position, could lead to significant changes in IOP. The 30-minute observation period adopted in this study was based on the average time reported for elective video-laparoscopic procedures in animals (CASE et al., 2015). Video-laparoscopic procedures must begin with the patient at $180^{\circ}$ and the Trendelenburg position used only when strictly necessary, and never at an angle greater than $45^{\circ}$ (BRUN, 2015).

The use of mechanical ventilation in videosurgery procedures is common (PEDROSO et al., 2007), however, there is a possibility of respiratory acidosis, as a result of the pneumoperitoneum diaphragmatic compression and potencilized by the respiratory depressant action of the inhaled anesthetic. The decision to keep the animals under spontaneous ventilation was based on the lack of significant clinical alterations reported in cats subjected to induced pneumoperitoneum under this type of ventilation (ANDRADE JUNIOR, 2009; CASE et al., 2015), nevertheless the data of this study showed a temporal respiratory depress with moderate respiratory acidosis.

Studies in cats have reported the use intraabdominal pressure (IAP) of $6-12 \mathrm{mmHg}$ (HONSHO et al., 2013; PINTO FILHO et al., 2014; CASE et a., 2015); the use of IAP of $10 \mathrm{mmHg}$ was based in a previous study reported is sufficient for an abdominal procedure in cats (NORMANDO et al., 2006).

Isofluorane did not cause significant changes in the HR of cats kept under spontaneous ventilation for 90 minutes (HIKASA et al., 1996). In isoflurane anesthetized cats and induced $\mathrm{CO}_{2}$ pneumoperitoneum ( 6 and $12 \mathrm{mmHg}$ ), observed an increase in HR in the first 15 minutes (ANDRADE JUNIOR, 2009). An increase in HR is often observed as a compensatory mechanism to the reduction in cardiac deficit; however, the results from the present study did not follow this tendency, probably due to a different compensatory mechanism (ALMEIDA et al., 2003).

In patients submitted to pneumoperitoneum, it is common to observe an increase in $f$ (LEME et al., 2002) due to the reduction in pulmonary complacency and increase in $\mathrm{PaCO}_{2}$ (NORMANDO et al., 2006; LEME et al., 2002). Andrade Junior (2009) reported that respiratory rate remained unchanged in cats subjected to induced pneumoperitoneum of 6 and $12 \mathrm{mmHg}$; contrary to the observed in this study, in which a reduction in $f$ was observed in GTREN. This reduction could be due to vagal stimulation, as HR also decreased at the same time in this group.

Reduction in cardiac deficit and venous return, hormonal action and, induced by anesthetic drugs are the main factors involved in changes in arterial pressure (ALMEIDA et al., 2003). In spontaneously breathing cats anesthetized with isoflurane $(1.5 \%)$ during 90 minutes, did not occur significant changes in MAP (HIKASA et al., 1996). 
An increase in MAP has been reported in humans (PEDROSO et al., 2007) and rats during induced pneumoperitoneum (BOTTER et al., 2005). In the present study, as a similar report by Andrade Junior (2009), MAP was increased in control group, probably as a consequence of the pneumoperitoneum.

Pneumoperitoneum reduces venous return and increase CVP, consequently, there is an increase in episcleral venous pressure (LENTSCHENER et al, 1998; AWAD et al., 2009; MONDZELEWSKI et al., 2015), which associated with high free $\mathrm{CO}_{2}$ in the abdominal cavity results in an increase in IOP (LENTSCHENER et al, 1998; AWAD et al., 2009; HOSHIKAWA et al., 2014). This raise in IOP can be aggravated by time and by the Trendelenburg position, as observed in this study, in which pneumoperitoneum alone did not significantly affect IOP but significant changes were observed in animals subjected to Trendelenburg position (AWAD et al., 2009; MONDZELEWSKI et al., 2015). In rabbits and humans submitted to pneumoperitoneum and/or trendelenburg position were noted increase in the IOP (LENTSCHENER et al., 1998; AWAD et al., 2009).

The mean values of IOP observed in this study were within the normal range for cats, the increase in IOP in GTREN suggests that from this time onwards the variations in IOP would have been more significant had this variable been analysed for longer. Thus, further studies in cats are needed to determine the behaviour of this and other variables for longer periods of time, since the period during which patients are kept in Trendelenburg position and the increase in IOP are determining factors in the occurrence and severity of visual changes in these patients (LENTSCHENER et al, 1998; AWAD et al., 2009; HOSHIKAWA et al., 2014).).

Changes in OPP are of clinical significance, as if increased for long periods of time it can cause ischemia of the optic nerve leading to blindness (TANI et al., 2014), as reported in humans following video-laparoscopic procedures (KUMAR; VYAKARNAM, 2013). In the present study, neither of the groups showed alterations in OPP, demonstrating that even though IOP increased due to the Trendelenburg position, it was not enough to significantly affect OPP.

An increase in $\mathrm{PaCO}_{2}$ is expected in videoassisted procedures, as it is related to the absorption of free $\mathrm{CO}_{2}$ (ALMEIDA et al., 2003; LEMOS et al., 2003; BOTTER et a., 2005; AWAD et al., 2009) in the abdomen, the difficulty in breathing caused by the intra-abdominal pressure (LEME et al., 2002; BOTTER et a., 2005; NORMANDO et al., 2006).
The regulation of blood $\mathrm{pH}$ occurs by ventilation and metabolic mechanisms; through the elimination of $\mathrm{CO}_{2}$ and re-absorption of bicarbonate, respectively. Therefore, a disruption in the elimination of $\mathrm{CO}_{2}$ leads to increases in $\left[\mathrm{HCO}_{3}{ }^{-}\right]$ (DiBARTOLA, 2011). In the present study, these effects were evident in animals from GTREN, in which respiratory acidosis with activating compensatory components was present, although it was incapable of controlling $\mathrm{pH}$. Both groups showed an increase in $\mathrm{PaCO}_{2}$; but in GTREN it was significantly increased in all times of evaluation, suggesting that the Trendelenburg position can intensify the changes caused by the pneumoperitoneum.

Hypoxemia $\left(\mathrm{PaO}_{2}<60 \mathrm{mmHg}\right)$ it's a common disorder in airless patients (BOTTER et al., 2005). $\mathrm{PaO}_{2}$ unchanged in both groups, it can be suggested that even though the pneumoperitoneum and the Trendelenburg position were unable to significantly affect the availability of $\mathrm{PaO}_{2}$, but the animals received $100 \%$ oxygen and, others ventilation variables were not analyzed; therefore, it was not possible to evaluate whether hypoxaemia occurred.

A previous study has demonstrated correlation between IOP and $\mathrm{PaCO}_{2}$ (TALIERI et al., 2005). However, in the present study this correlation was not observed. Furthermore, there was a poor correlation between IOP and MAP, corroborating with Ozcan et al. (2004), and thus suggesting that gravity was the main cause of the increase in IOP in the present study.

It was evident that the Trendelenburg position caused significant changes in IOP, even though its values were within the physiological range. It also led to important changes in $\mathrm{pH}$ and $\mathrm{PaCO}_{2}$, suggesting that the combination of induced pneumoperitoneum and Trendelenburg position should not be used in circumstances similar to those of this study. However, these results must be interpreted with caution to practice clinical application, due to the limited number of animals used, ventilation, and haemodynamic variables that could have provided a more accurate interpretation of the results.

It can be concluded that an induced pneumoperitoneum of $10 \mathrm{mmHg} \quad \mathrm{CO}_{2}$ did not significantly affect IOP or OPP in cats anaesthetised with isofluorane and kept under spontaneous ventilation. However, induced pneumoperitoneum combined with Trendelenburg position resulted in an increase in IOP in cats subjected to the same anaesthetic conditions, but did not affect OPP. No 
correlation was observed between MAP and IOP, and $\mathrm{PaCO}_{2}$ hardly influenced the later.

\section{Bioethics And Committee Approval Biossecurity}

Ethics Committee for the Use of Animals (CEUA-UNIFRAN, Franca-SP, Brazil) has approved the methods employed in this study (Protocol n. 036/13).

\section{ACKNOWLEDGEMENT}

This study was financed in part by the Coordenação de Aperfeiçoamento de Pessoal de Nível Superior (CAPES 1267979), and Fundação de Amparo à Pesquisa do Estado de São Paulo (FAPESP 2014/09250-2)

RESUMO: O objetivo deste estudo foi determinar se o pneumoperitônio de $10 \mathrm{mmHg}$ associado, ou não, à posição de Trendelenburg poderia levar a alterações significativas na Pressão Intraocular (PIO), Pressão de Perfusão Ocular (PPO) e variáveis cardiorrespiratórias, bem como determinar se havia correlação entre a PIO e a Pressão Arterial Média (PAM) e/ou Pressão Parcial de Dióxido de Carbono no Sangue Arterial $\left(\mathrm{PaCO}_{2}\right)$ em gatos. Os animais foram alocados em dois grupos $(\mathrm{n}=7 /$ grupo): $\mathrm{GC}$ (sem inclinação) e GTREN (posição de Trendelenburg). As variáveis foram registradas antes (linha de base) e durante 30 minutos (T5-T30) após a insuflação. No GTREN, foi observada redução na frequência cardíaca em T5 e, na frequência respiratória, em T5 e T15. Houve aumento da PIO no T5-T30 comparativamente ao valor basal. Houve redução no Potencial de Hidrogênio no sangue arterial em ambos os grupos em todos os momentos comparativamente à linha de base. A Pressão Parcial de Dióxido de Carbono no sangue arterial aumentou em T15-T30 no GC e em T5-T30 no GTREN. Concluiu-se que o pneumoperitônio de $10 \mathrm{mmHg} \mathrm{CO}_{2}$ não afetou significativamente a PIO ou a PPO em gatos anestesiados com isofluorano e mantidos sob ventilação espontânea. No entanto, o pneumoperitônio induzido combinado à posição de Trendelenburg resultou em aumento da PIO em gatos submetidos às mesmas condições anestésicas, mas não afetou a PPO.

PALAVRAS-CHAVE: Pressão Intra-abdominal. Posição corporal. Alterações oculares. Pressão. Videolaparoscopia. Videocirurgia.

\section{REFERENCES}

ALMEIDA, A. V.; GANEM, E. M.; CARRARETTO, A. R.; VIANNA, P. T. G. Alterações hemodinâmicas durante o pneumoperitônio em cães ventilados com volume e pressões controlados. Revista Brasileira de Anestesiologia, v. 53, n. 6, p. 756-766, 2003. https://doi.org/10.1590/S0034-70942003000600007.

ANDRADE JUNIOR, P. S. C. Avaliação do pneumoperitônio com CO2 em gatos (Felis catus) anestesiados com isofluorano: parâmetros cardiorrespiratórios. 2009. 57f. Dissertação (Mestrado em Ciência Animal), Universidade Estadual do Norte Fluminense.

http://www.uenf.br/Uenf/Downloads/PGANIMAL_3897_1260794578.pdf. Last accessed October 16, 2017.

AWAD, H.; SANTILLI, S.; OHR, M.; ROTH, A.; YAN, W.; FERNANDEZ, S.; ROTH, S.; PATEL, V. The effects of steep Trendelenburg positioning on intraocular pressure during robotic radical prostatectomy. Anesthesia and Analgesia, v. 109, p. 473-478, 2009. https://doi.org/10.1213/ane.0b013e3181a9098f.

BASSO, P. C.; RAISER, A. G.; BRUN, M. V.; MÜLLER, D.C.M.; LUKARSEWSKI, R.; SERAFINI, G.M.C.; FREITAS, G.C.; DUTRA, L.H.; MARCONATO, F. Ovariosalpingohisterectomy in bitches: comparison of pain, cardiopulmonary, pressure and arterial blood gas analysis of the conventional approaches, by NOTES hybrid and NOTES pure. Arquivo Brasileiro de Medicina Veterinária e Zootecnia, v. 66, p. 1329-1338, 2014. http://dx.doi.org/10.1590/1678-6671.

BOTTER, F. C. S.; TAHA, M. O.; FAGUNDES, D. J.; FAGUNDES, A. T.; NEGRINI. The role of pneumoperitoneum in the respiratory and hemodynamic evaluation in anaesthetized rats, with or without intubation. Revista do Colégio Brasileiro de Cirurgiões, v. 32, n. 5, p. 261-266, 2005.

https://doi.org/10.1590/S0100-69912005000500008. 
BRUN, M. V. Equipe cirúrgica e ambiente operatório In: BRUN, M. V. Videocirurgia em pequenos animais, Rio de Janeiro, Rio de Janeiro: Roca, 2015, p.98.

CASE, J. B.; BOSCAN, P. L.; MONNET, E. L.; NIYOM, S. R.; IMHOFF, D. J.; WALLACE, M. L.; SMEAK, D. D. Comparison of surgical variables and pain in cats undergoing ovariohysterectomy, laparoscopic-assisted ovariohysterectomy, and laparoscopic ovariectomy. Journal of American Animal Hospital Association, v. 51, n. 1, p. 1-7, 2015. https://doi.org/10.5326/JAAHA-MS-5886.

DIBARTOLA, S. P. Fluid, Electrolyte, and Acid-Base Disorders in Small Animal Practice, 4th ed. St. Louis, USA: Elsevier Saunders, 2011. p. 231-252. https://doi.org/10.1016/B978-1-4377-0654-3.00016-0.

HIKASA, Y.; KAWANABE, H.; TAKASE, K.; OGASAWARA, S. Comparison of sevoflurane, isoflurane and halothane anesthesia in spontaneously breathing cats. Veterinary Surgery, v. 25, p. 234-243, 1996.

https://doi.org/10.1111/j.1532-950X.1996.tb01407.x.

HONSHO, C. S.; MATTOS-JUNIOR, E.; TAVARES, D. C.; QUARTERONE, C.; MORAES, C. B. L. Efeitos do procedimento de videocirurgia sobre a pressão ocular (PO) em gatos. Enciclopédia Biosfera, v.9, n. 16, p. 941-951, 2013. http://www.conhecer.org.br/enciclop/2013a/agrarias/efeitos\%20do\%20procedimento.pdf. Last accessed October 16, 2017.

HOSHIKAWA, Y.; TSUTSUMI, N.; OHKOSHI, K.; SERIZAWA, S.; HAMADA, M.; INAGAKI, K.; TSUZUKI, K.; KOSHIMIZU, J.; ECHIZEN, N.; FUJITANI, S.; TAKAHASHI, O.; DESHPANDE, G. A. The effect of steep trendelenburg positioning on intraocular pressure and visual function during robotic-assisted radical prostatectomy. British Journal of Ophthalmology, v. 98, n. 3, p. 305-382, 2014.

https://doi.org/10.1136/bjophthalmol-2013-303536.

KUMAR, G.; VYAKARNAM, P. Postoperative vision loss after colorectal laparoscopic surgery. Surgery, Laparoscopy and Endoscopy Percutaneous Techinics, v. 23, n. 2, p. E87-E88, 2013. https://doi.org/10.1097/SLE.0b013e318277d2ae.

LEME, M. C.; NATALINI, C. C.; BECK, C. A. C.; BRUN, M. V.; CONTESINI, E. A.; LIMA, S. D. A.; STEDILE, R. Pneumoperitônio com dióxido de carbono associado a três posições para laparoscopia em cães. Ciência Rural, v. 32, n. 2, p. 281-287, 2002. http://dx.doi.org/10.1590/S0103-84782002000200016.

LEMOS, S. L. S.; VINHA, J. M.; SILVA, I. S.; NOVAES, P. A. C.; OLIVEIRA, M. F.; PAULA, G. B.; REBELO, C. C.; MARINHO, M. L. Effects of $\mathrm{CO} 2$ and air pneumoperitoneum on blood gas changes in pigs. Acta Cirúrgica Brasileira, v. 18, n. 5, p. 445-451, 2003. http://dx.doi.org/10.1590/S0102-86502003000500010.

LENTSCHENER, C.; LEVEQUE, J. P.; MAZOIT, J. X.; BENHAMOU, D. The effect of pneumoperitoneum on intraocular pressure in rabbits with alpha-chymotrypsin induce glaucoma. Anesthesia and Analgesia, v. 86, p. 1283-1288, 1998. https://doi.org/10.1097/00000539-199806000-00029.

MOLLOY, L. B. Implications for postoperative visual loss: steep trendelemburg position and effects on intraocular pressure. Journal American Association of Nurse Anesthetists, v. 79, p. 115-121, 2011.

MONDZELEWSKI, T. J.; SCHMITZ, J. W.; CHRISTMAN, M. S.; DAVIS, K. D.; LUJAN, E.; L'ESPERANCE, J. O.; AUGE, B. K. Intraocular pressure during robotic-assisted laparoscopic procedures utilizing steep trendelenburg positioning. Journal of Glaucoma, v. 24, n. 6, p. 399-404, 2015. https://doi.org/10.1097/IJG.0000000000000302.

NORMANDO, V. M. F.; BRITO, M. V. H.; ARAÚJO JÚNIOR, F. A. ALBUQUERQUE, B. C. M. Repercussões do pneumoperitônio na amplitude da excursão diafragmática em suínos. Jornal Brasileiro de Pneumologia, v. 32, n. 1, p. 216-223, 2006. https://doi.org/10.1590/S1806-37132006000100006. 
OZCAN, M.S.; PRAETEL, C.; BHATTI, M. T.; GRAVENSTEIN, N.; MAHLA, M. E.; SEUBERT, C. N. The effect of body inclination during prone positioning on intraocular pressure in awake volunteers: a comparision of two operating tables. Anesthesia and Analgesia, v. 99, n. 4, p. 1152-1158, 2004.

https://doi.org/10.1213/01.ANE.0000130851.37039.50.

PEDROSO, A. M. G.; MARUBAYASHI, L.; GORI, R.; PEDROSO, M. A.; LUPINACCI, R. A. Relevants Aspects of anesthesia in laparoscopic colorectal surgery. Revista Brasileira de Coloproctologia, v. 27, n. 3, p. 284-287, 2007. http://dx.doi.org/10.1590/S0101-98802007000300006.

PINTO FILHO, S. T. L.; OLIVEIRA, M. T.; SOUZA, F. W; DALMOLIN, F.; HARTMANN, H.; COUTINHO JÚNIOR, A. S.; SCHUSTER, L. A. H.; BECK, C. A. C.; SANTOS, F. R. B.; FERANTI, J. P. S.; BRUN, M. V. Uretrostomia pré-púbica videoassistida em um felino com estenose uretral. Semina: Ciências Agrárias, v. 35, n. 1, p.381-386, 2014. http://dx.doi.org/10.5433/1679-0359.2014v35n1p381.

TALIERI, I. C.; HONSHO, C. S.; NUNES, N.; SOUZA, A. P.; DUQUE, J. C. Behavior of intraocular pressure according to cardiorespiratory and hemodynamic effects induced by desflurane in dogs subjected to experimental hypovolemia. Arquivo Brasileiro de Oftalmologia, v. 68, n. 4, p. 521-526, 2005.

https://doi.org/10.1590/S0004-27492005000400018

TANI, T.; NAGAOKA, T.; NAKABAYASHI, S.; YOSHIOKA, T.; YOSHIDA, A. Autoregulation of retinal blood flow in response to decreased ocular perfusion pressure in cats: comparison of the effects of increased intraocular pressure and systemic hypotension. Investigative Ophthamology and Visual Science, v. 55, n. 1, p. 360-367, 2014. https://doi.org/10.1167/iovs.13-12591 